BUSTANUL FUQAHA: Jurnal Bidang Hukum Islam

Vol. 1, No. 1 (2020) : Hal. 28-43

Website: httpas://journal.stiba.ac.id

\title{
KONSEP DASAR IJMAK SEBAGAI SUMBER HUKUM ISLAM
}

\author{
Ahmad Syaripudin \\ Sekolah Tinggi Ilmu Islam dan Bahasa Arab (STIBA) Makassar \\ Email: ahmadsyaripudin@stiba.ac.id \\ M. Kasim \\ Sekolah Tinggi Ilmu Islam dan Bahasa Arab (STIBA) Makassar \\ Email: m.kasim@stiba.ac.id
}

\begin{abstract}
Keywords : ABSTRACT

koran, hadis, consensus, This study aimed to describe the basic concept of consensus as fiqh, law source of Islamic law. The description of basic concept of consensus consists of: 1) definition of consensus; 2) status of consensus as a fundament of Islamic knowledge and law; 3) types of consensus; 4) examples of consensus in terms of classical and contemporary Islamic jurisprudence; and 5) law of refutation against consensus. The research applied a qualitative-descriptive approach with library research methods combined with content analysis of a number of books and related articles. The results show that: 1) consensus is an agreement of scholars of mujtahid among the people of Prophet Muhammad saw. on an shari issue that is not obviously found in the Koran and hadis in the period after the Prophet which has specific pillars and conditions; 2) of consensus in its position as a source of knowledge and Islamic law is in the third row after the Koran and hadis; 3) types of consensus include sarīh consensus and sukūtī consensus, and some divides it into qat' $i$ consensus and dzanni consensus; 4) some examples of consensus: a) forms of classical Islamic jurisprudence consensus: the agreement of the scholars regarding the prohibition of marrying grandmother and granddaughter, that grandson and son are in one position in terms of inheritance division, that inheritance portion for grandmother is one sixth if there is no mother, and consensus of the companions to codify the Koran owing to benefits that appeared during the caliphate of Abu Bakr al-Shiddiq ra. b) Forms of contemporary Islamic jurisprudence: validity of human organ transplants, brain death, animal and human cloning, joint-stock companies, stock exchanges, globalization, and compliance with international institutions, regulations and laws such as world education organizations and world trade organizations; and 5) law of those who refute consensus in absolute manner (totality) are considered disbelievers.
\end{abstract}

\begin{tabular}{ll} 
Kata kunci : $\begin{array}{c}\text { ABSTRAK } \\
\text { al-qur'an, hadis, ijmak, } \\
\text { fikih, hukum }\end{array}$ & $\begin{array}{l}\text { Penelitian ini bertujuan untuk untuk mendeskripsikan konsep } \\
\text { dasar ijmak sebagai sumber hukum Islam. Deskripsi konsep dasar }\end{array}$ \\
& $\begin{array}{l}\text { ijmak terdiri dari: 1) pengertian ijmak; 2) kedudukan ijmak } \\
\text { sebagai landasan ilmu dan hukum Islam; 3) jenis-jenis ijmak; 4) } \\
\text { bentuk-bentuk ijmak dalam masalah fikih klasik dan kontemporer; } \\
\text { dan 5) hukum bagi orang yang mengingkari ijmak. Adapun }\end{array}$ \\
\hline
\end{tabular}


Vol. 1, No. 1 (2020) : Hal. 28-43

Website: httpas://journal.stiba.ac.id

penelitian ini menggunakan pendekatan kualitatif-deskriptif dengan metode riset kepustakaan (library research) berpadu analisis konten (content analysis) dari sejumlah kitab turats dan artikel relevan. Hasil penelitian menunjukkan bahwa: 1) ijmak adalah kesepakatan para ulama mujtahid dari umat Nabi Muhammad saw. atas persoalan syar'î yang tidak ditemukan dalilnya secara jelas dalam al-Qur'an dan hadis pada suatu masa setelah masa Nabi saw. yang mempunyai rukun-rukun dan syaratsyarat tertentu; 2) kedudukan ijmak dalam posisinya sebagai sumber ilmu dan hukum Islam menempati deretan ketiga setelah al-Qur'an dan hadis; 3) jenis ijmak di antaranya ialah ijmak șan̄h dan ijmak sukūtī, dan ada yang membagi menjadi ijmak Qat'i dan Ijmak Dzanni; 4) beberapa contoh ijmak: a) bentuk ijmak fikih klasik: kesepakatan para ulama tentang keharaman menikahi nenek dan cucuk perempuan, posisi cucuk laki-laki dari anak lakilaki dalam pembagian waris satu posisi, bagian warisan bagi nenek mendapatkan bagian 1/6 ketika tidak ada ibu, dan ijmak sahabat untuk mengkodifikasi al-Qur' an karena ada maslahat positif yang tampak dapat dilakukan pada masa khalifah Abu Bakar al-Shiddiq ra. b) bentuk ijmak fikih kontemporer: keabsahan dalam transplantasi organ manusia, kematian otak, kloning hewan dan manusia, perusahaan saham gabungan, pertukaran saham, globalisasi, dan kepatuhan terhadap lembaga internasional, peraturan dan undang-undang seperti organisasi pendidikan dunia dan organisasi perdagangan dunia; dan 5) hukum orang yang mengingkari ijmak secara mutlak (totalitas) ini adalah dihukumi kafir.

\section{PENDAHULUAN}

Umat Islam adalah yang terakhir dari umat-umat yang ada, dan Nabi Muhammad saw. adalah Nabi terakhir dari para nabi yang diutus oleh Allah swt. dikaruniai dua wahyu dari Allah swt. yaitu: al-Qur'an sebagai mukjizat yang bernilai ibadah otomatis ketika membacanya secara khusus, dan hadis mukjizat yang bernilai ibadah ketika membacanya secara umum. Semuanya disampaikan melalui Nabi Muhammad saw. yang maksum dan terjaga dari penyimpangan dan kesalahan. Tetapi dua wahyu ini sebagai sumber ilmu dan hukum Islam telah terputus oleh wafatnya Rasulullah saw. sedangkan teks-teks wahyu al-Qur'an dan sunah terbatasi, dan tidak ada yang boleh menambahkan apapun atas kedua wahyu tersebut, siapapun dia, dan Allah swt. memastikan orisinalitas dan validitas kitab-Nya (al-Qur'an) melalu firman-Nya dalam Q.S. al-Hijr/16: 9,

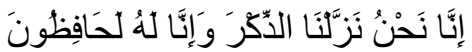

Terjemahan: "Sesungguhnya Kamilah (Allah) yang menurunkan al-Qur'an, dan sesungguhnya Kami (Allah) benar-benar memeliharanya." 
Begitupun para ulama telah berikhtiar mengodifikasi sunah Rasulullah saw. dan memisahkan hadis yang valid (sahih) sebagai hujah dalil dari hadis yang lemah (da'if) bukan hujah dalil.

Permasalahan-permasalahan baru (kontemporer) tidak akan berakhir selama kehidupan masih manusia hidup di bumi ini, dan manusia dituntut untuk mengetahui ketentuan dan hukum dalam menyikapi masalah-masalah baru yang bermunculan satu persatu. Bagi para ulama, ada pedoman al-Qur'an dan bimbingan dari sunah Nabi saw. dalam melakukan upaya dengan fokus dan penuh kesungguhan (berijtihad) untuk mengetahui hukum syar'i dalam masalahmasalah kontempoter. Jika mereka bekerja bersama dan pandangan mereka satu (sepakat) tentang satu penilaian masalah hukum syar'i tertentu, maka hal ini disebut ijmak.

Berdasarkan apa yang disebutkan di atas, permasalahan yang hendak dijawab pada penelitian ini adalah: 1) Bagaimana gambaran konsep ijmak ulama?; 2) Bagaimana kehujahan ijmak sebagai landasan ilmu dan hukum Islam?; 3) Bagaimana gambaran jenis-jenis ijmak?; 4) Bagaimana bentuk aplikasi ijmak dalam masalah fikih klasik dan kontemporer?; dan 5) Bagaimana hukum jika seseorang mengingkari ijmak?.

Penelitian ini bertujuan untuk membahas tinjauan hukum berkaitan dengan Ijmak Sebagai Sumber Hukum Islam, yaitu: 1) Konsep ijmak; 2) Kehujahan ijmak sebagai landasan ilmu dan hukum Islam; 3) Jenis-jenis ijmak; 4) Bentukbentuk aplikasi ijmak dalam masalah fikih klasik dan kontemporer; dan 5) Hukum jika seseorang mengingkari ijmak.

Untuk mencapai tujuan di atas, maka penelitian ini menggunakan pendekatan kualitatif-deskriptif dengan metode riset kepustakaan (library research) yaitu menggunakan data atau bahan yang diperoleh dari hasil penelitian, artikel dan buku-buku referensi yang membahas topik yang berkaitan dengan tema penelitian. ${ }^{1}$ Sumber data primer dalam penelitian ini adalah al-Qur'an dan hadis, serta pendapat ulama dalam kitab turats. Sumber data sekunder diperoleh dari artikel relevan dengan penelitian ini. Adapun analisis isi (content analysis) diterapkan untuk kebutuhan filterisasi data yang disesuaikan dengan tujuan penelitian.

${ }^{1}$ Iskandar, A., Aqbar, K. (2019). Green Economy Indonesia Dalam Perspektif Maqashid Syari'ah. Al-Mashrafiyah: Jurnal Ekonomi, Keuangan, dan Perbankan Syariah,3(2), h.83-94. 
Penelitian terkait pengetahuan akan ijmak sebagai sumber hukum Islam sangat urgen dilakukan dikarenakan ada kaitannya dengan salah satu sumber pengambilan ilmu dan hukum Islam setelah al-Qur'an dan hadis sahih. Juga adanya fenomena sebagian akademisi mengaku mengkaji ajaran Islam tetapi dalam pemahaman terjadi kerancuan dan berbeda dengan penjelasan dan kesepakatan ulama kita, bahkan sampai berani menghalalkan yang haram. Ternyata jika dikaji lebih lanjut asal-usulnya adalah minimnya pengetahuan mereka terhadap konsep ijmak dalam Islam.

\section{PEMBAHASAN}

\section{Pengertian Ijmak}

Menurut bahasa (etimologi) kata ijmak berasal dari bahasa arab ajma'ayujmi'u yang mengandung dua arti. Pertama, ketetapan hati untuk melakukan sesuatu, atau memutuskan untuk berbuat sesuatu. Kedua, mengandung arti kesepakatan (al-Ittifăq). Makna ijmak yang pertama didasarkan pada firman

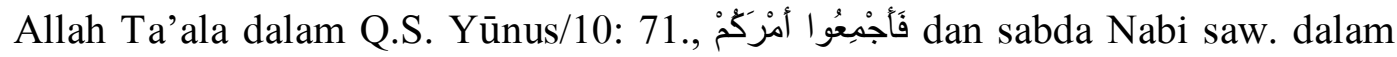

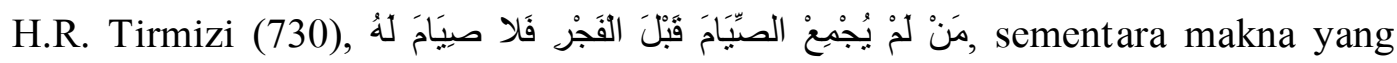

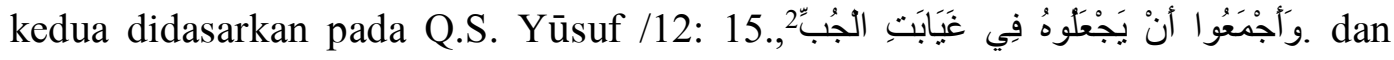

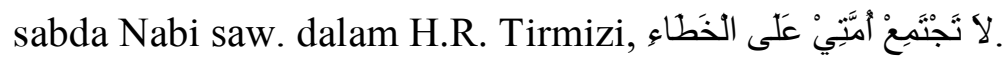

Adapun pengertian ijmak menurut istilah (terminologi) para ulama Ușū Fiqh, ada beberapa pendefinisian beragam yang membutuhkan penjelasan panjang lebar sebagaimana dikemukakan oleh penulis kitab al-Kaukab al-Munir Syarah Mukhtasar al-Tahrir. ${ }^{3}$ Di antara definisi ijmak menurut istilah yang disebutkan Abdul Hamid Hakim dalam bukunya al-Sullam adalah kesepakatan para imam mujtahid tentang suatu problematika pada suatu masa setelah masa Rasulullah saw. ${ }^{4}$ Definisi lain yang mempunyai kesamaan secara subtansial dikemukakan oleh Abd. Al-Karīm Zaidān dalam al-Waj̄̄z fi Ușūl al-Fiqh. ${ }^{5}$ Antara dua definisi yang dikemukakan oleh dua ulama tersebut, terdapat sedikit perbedaan dalam menentukan perkara yang disepakati. Abdul Hamid menyebut amrin min al-umūri, sementara 'Abdu al-Karìm membatasinya

\footnotetext{
${ }^{2}$ Amir Syarifuddin, Ushul Fiqh, Jilid 1. (Cet. V; Jakarta: Kencana Prenada Media Group, 2011), h. 132.

${ }^{3}$ Muhammad bin Ahmad bin Abd al-Aziz Ibn al-Najar, al-Kaukab al-Munir Syarah Mukhtasar al-Tahrir, Jilid 1, (Cet. I; Maktabah al-'Abikan, 1997). h. 220. 41.

${ }^{4}$ Abdul Hamid Hakim, al-Sullam, Juz 2. (Cet. I; Jakarta: Maktab Sa'adiyah Putra, 2007), h.

5'Abd al-Karīm Zaidān, al-Waj̄̄z fi Ușūl al-Fiqh (Maktab al-Basyāir: Muassasah al-Risālah), h. 179 .
} 
pada hukum syar'̄. Atas dasar kesepakatan para imam mujtahid, ijmak dapat dijadikan dalil hukum syar'i dan kredibilitasnya menempati urutan ketiga setelah nas al-Qur'an dan hadis.

Dari definisi di atas terdapat beberapa batasan dalam perumusannya. Batasanbatasan tersebut antara lain: pertama, ittifă $q$ (kesepakatan), keluaran dari batasan ini adalah hasil analisis yang dilakukan oleh satu orang, maka tidak bisa disebut Ijmak. Kedua, mujtahid (orang yang berijtihad), keluaran dari mujtahid adalah pendapat para muttabi' dan muqallid, pendapat mereka tidak dapat disebut sebagai ijmak. Ketiga, umat Muhammad saw., maka kesepakatan yang dilakukan oleh selain umat Muhammad saw. (selain orang Islam) tidak termasuk ijmak dalam pembahasan ini. Keempat, dibatasi dengan wafatnya Rasulullah saw., kesepakatan yang dilakukan oleh para sahabat pada masa hidup Nabi saw. tidak dianggap sebagai ijmak dalam posisinya sebagai sumber atau dalil hukum. Sebab, sumber hukum pada masa Nabi saw. hanya terbatas pada al-Qur'an dan sunah. Semua permasalahan harus dikembalikan pada keduanya dengan cara mengonfirmasikan kepada Nabi saw. terhadap beberapa masalah yang secara tegas tidak terdapat dalilnya dalam alQur'an. Kelima, hukum syar'̄, kesepakatan dalam hukum adat dan hukum akal tidak termasuk kategori ijmak. Sebab, ijmak hanya berkaitan dengan dalildalil syar' ’. Pada dasarnya konsep ijmak memiliki kesamaan dengan konsep syūrā, dalam mana terbatas pada permasalahan yang tidak memiliki nas (dalil tegas) atau permasalahan yang memiliki nas, namun indikasi yang ditunjukkan memiliki beberapa pemahaman, syūrā hanya dibutuhkan dalam menentukan mekanisme pelaksanaan nușuṣal-syara'. ${ }^{6}$ Hanya saja konsep dasar ijmak dibatasi oleh konsensus imam mujtahid yang membedakannya dari konsep syūrā yang bersifat umum dalam musyawarah untuk memperoleh mufakat.

Terkait siapa saja yang berhak bersepakat dalam memutuskan suatu hukum atas suatu masalah, terdapat perbedaan pendapat secara teknis di kalangan para ulama. Secara umum ijmak yang kuat adalah ijmak salaf saleh yaitu kesepakatan para sahabat, tabiin dan orang-orang yang mengikuti mereka. ${ }^{7}$ Al-Zarkasyi merumuskan definisi ijmak menurut istilah sebagai berikut (artinya): "Kesepakatan semua mujtahid dari umat Muhammad, pada suatu masa setelah wafatnya Rasulullah saw., terhadap suatu hukum syarî." Rumusan ijmak yang

${ }^{6}$ Bakry, K. (2018). Konsep Syūrā dalam al-Quran. NUKHBATUL'ULUM: Jurnal Bidang Kajian Islam, 4(1), 70-83.

${ }^{7}$ Ahmad Syaripudin, Buku Ajar Metodologi Studi Islam, (Cet. I; Surabaya: Pustaka Media Guru, 2019), h. 14.

${ }^{8}$ Badr al-Din Muhammad ibn 'Abdillah Al-Zarkasyî, Al-Bahr al-Muhith fi Ushul al-Fiqh, Jilid. 6, (Cet. II; Wizaratul Auqaf, 1992), h. 379. 
dikemukakan oleh al-Zarkasyi ini bermakna bahwa ijmak hanya bisa melibatkan orang Islam yang telah menyandang gelar mujtahid. Ijmak juga hanya berkaitan dengan hukum syar', yaitu ketetapan Allah swt., yang bekaitan dengan perbuatan orang mukallaf. Seperti hukum wajib, haram, sunah dan lainnya. Sementara kesepakatan atas masalah yang bukan syar' termasuk ijmak dalam konteks ini seperti kesepakatan atas masalah kesehatan, pengobatan dan bahasa. Definisi yang dikemukakan oleh al-Zarkasyi bagi penulis adalah definisi terbaik, lebih tepat dan jelas dalam memberikan batasan-batasan terkait ijmak.

\section{Rukun dan Syarat-syarat Ijmak}

Sebagaimana telah diuraikan di atas, bahwa ijmak adalah kesepakatan para mujtahid pada suatu masa setelah wafatnya Rasulullah saw., atas hukum syar'î. Abdul Wahab Khallaf dalam bukunya Ilm Ușūl Fiqh menyimpulkan bahwa rukun ijmak ada empat. ${ }^{10}$ Keempat rukun itu adalah sebagai berikut:

1. Pada waktu terjadinya suatu kejadian yang diselesaikan dengan cara ijmak harus ada beberapa ('adadun) mujtahid yang terlibat di dalamnya. Tidak dapat dikatakan sepakat apabila hanya pendapat satu orang atau pendapat banyak orang, tapi antara satu dengan yang lainnya menyajikan pendapat yang berbeda. Oleh karenanya, ijmak dalam konteks ini tidak pernah terjadi pada masa Nabi saw., karena para shahabat sekalipun melakukan ijtihad, mereka melakukannya secara individu. Seperti kasus Mu'ād bin Jabal ra. yang menjadi duta Rasulullah saw. ke Yaman untuk memutuskan suatu kasus.

2. Imam mujtahid yang terlibat dalam ijmak atas hukum syar $\bar{\imath}$ harus mencakup keseluruhan para imam mujtahid di seluruh penjuru dunia. Kalau yang bersepakat hanya mujtahid di suatu daerah atau kota tertentu, maka tidak dianggap ijmak.

3. Kesepakatan dari para mujtahid atas hukum syar'̄ harus diawali dengan mempresentasikan pendapat masing-masing dari para mujtahid.

4. Kesepakatan atas hukum syar'i tersebut harus benar-benar melibatkan semua mujtahid. Tidak disebut ijmak, jika yang bersepakat hanya sebagian, sementara yang lainnya berbeda. Sebab, jika ada sebagian (kecil) yang berbeda, itu artinya masih ada kemungkinan salah (ihtimāl) salah dan ada kemungkinan (ihtimāl) benar. Kesepakatan yang hanya terdiri dari sebagian

\footnotetext{
${ }^{9}$ Ahmad bin Muhammad bin 'Alī al-Wazīr, al-Mușțafă fi Ușūl al-Fiqh (Cet. I; Beirut: Dar alFikr, 1996), h. 82.

${ }^{10}$ Abdul Wahab Khallaf, Ilm Ușūl Fiqh (Cet. XII; Dār al-Fikr, 2002), h. 45.
} 
besar para mujtahid tidak bisa dijadikan hujjah syar'iyah.

Dari keempat rukun ijmak di atas, Nasrun Haroen menambahkan satu rukun lagi yang tidak disebutkan oleh Abdul Wahab Khallaf yaitu ijmak harus didasarkan pada al-Qur'an dan hadis Nabi saw.. ${ }^{11}$ Hal ini sebagaimana digambarkan Allah swt. dalam Q.S. al-Nisā'/4: 59. Jadi, menurut Nasrun, rukun ijmak kesemuanya ada 5 (lima).

Di samping harus memenuhi beberapa rukun di atas, ijmak juga harus memenuhi beberapa persyaratan yang telah ditetapkan oleh para ulama. Syaratsyarat ijmak sangatlah beragam, sebagian ada yang disepakati oleh para ulama dan sebagian yang lain ada yang masih diperselisihkan. Pada paper ini, penulis hanya mengemukakan syarat-syarat ijmak yang sangat urgen. Hal ini sebagaimana disebutkan dalam al-Waj̄̄z fi Ușūl al-Fiqh al-Islāmī, yang mana Musțafā al-Zuhailī menyebutkan 7 (tujuh) syarat ijmak yang dianggap paling urgen. Antara lain adalah sebagai berikut: ${ }^{12}$

1. Ijmak yang disepakati oleh para mujtahid tidak boleh bertentangan dengan nas (al-Qur'an dan hadis) dan ijmak sebelumnya. Sebagaimana diketahui bahwa ijmak sebagai dalil syar’̄ menduduki urutan ketiga setelah al-Qur'an dan hadis, dan ijmak harus disandarkan pada naș. Dengan demikian, ijmak tidak dibenarkan apabila bertentangan dengan al-Qur'an dan hadis. Ijmak juga tidak boleh bertentangan dengan ijmak sebelumnya.

2. Ijmak harus disandarkan pada dalil-dalil syar`̄, yaitu al-Qur'an dan hadis, baik secara langsung atau tidak. Oleh karena para mujtahid tidak akan bisa sampai pada batas kebenaran tanpa ada rujukan atau sandaran. Pendapat ini didukung oleh Ibnu Hazm yang berkata bahwa "tidak ada ijmak kecuali disandarkan pada nas. ${ }^{\text {’3 }}$ Nabi saw. tidak pernah menetapkan suatu hukum kecuali bersandar pada wahyu, sebagaimana disebutkan oleh Allah dalam Q.S. Al-Najm/53: 3-4. Jika ijmak tidak punya landasan dalil, maka ia dinyatakan tidak sah. Terkait landasan ijmak ulama, maka mereka berbeda pendapat. Mayoritas ulama Ushul Fiqh berpendapat bahwa landasan ijmak terdiri dari dalil qat ' 1 , yaitu al-Qur'an dan hadis mutawatir. ${ }^{14}$

3. Para mujtahid yang terlibat dalam ijmak harus satu masa dan harus mencapai jumlah yang banyak (jumlah yang mencapai batas mutawatir) yaitu, jumlah yang tidak memungkinkan mereka (secara 'aqזi) bersepakat

\footnotetext{
${ }^{11}$ Nasrun Haroen, Usul Fiqh, (Jakarta: Logos Wacana Ilmu, 1997). h. 53.

${ }^{12}$ Muhammad Mușțafã al-Zuhailī, al-Waj̄z fi Ușūl al-Fiqh al-Islāmī (Cet. II; Beirūt: Dār alKhair, 2006), h. 234.

${ }^{13}$ Muhammad Mușțafā al-Zuhailī, al-Waj̄̄z fi Ușūl al-Fiqh al-Islāmī (Cet. II; Beirūt: Dār alKhair, 2006), h. 234.

${ }^{14}$ Nasrun Haroen, Usul Fiqh, (Jakarta: Logos Wacana Ilmu, 1997). h. 59.
} 
dalam kebohongan. Terkait batasan jumlah mutawatir dalam perawi hadis, ulama berbeda pendapat. Di antara mereka ada yang berpendapat sebanyak 4, 5, atau 10 orang (karena itulah minimal dari jama' katsrah). ${ }^{15}$ Ada juga yang berpendapat harus mencapai 40 orang, 50 orang bahkan ada yang berpendapat 300 orang bahkan lebih. ${ }^{16}$

4. Kesepakatan tersebut hanya bisa dilakukan oleh para imam mujtahid. kesepakatan yang tidak melibatkan para imam mujtahid tidak dapat dikategorikan ijmak dalam arti bahwa tidak bisa disebut sebagai sumber hukum Islam.

5. Menurut jumhūr ulama, ijmak hanya berlaku pada hukum syar't, tidak pada yang lain. Sementara sebagian yang lain berpedapat sebaliknya yaitu ijmak juga dapat berlaku pada semua perkara.

6. Berlalunya masa, maka syarat keenam ini masih diperselisihkan di kalangan para ulama. Sebagaimana diketahui bahwa ijmak harus dilakukan oleh para mujtahid pada satu masa. Ijmak berlaku sebagai sumber hukum Islam sejak ditetapkannya. Tidak harus menunggu wafatnya para mujtahid yang terlibat di dalamnya. Terkait wafatnya para imam mujtahid yang tergabung dalam ijmak menurut Imam Ahmad bin Hambal dan sebagian kecil ulama Syāfi'iyah merupakan salah satu syarat kekuatan hujah suatu ijmak. Argumentasi ini dapat diperkuat dengan sebuah contoh melalui pernyataan dari Amir Syarifuddin: ${ }^{17}$

"Pernah terjadi pendapat yang menyimpang dari ketentuan hukum yang telah ditetapkan suatu ijmak. Umpamanya, ummu alwalad (sahaya perempuan yang telah dihamili majikannya) menurut ijmak disamakan kedudukannya dengan hamba sahaya biasa, sehingga dapat dijual dan tidak merdeka dengan sendirinya dengan kematian tuannya. Atas dasar pendapat ijmak tersebut, maka Umar Ibnu Khattab memerdekakan seorang ummu al-waladnya. Setelah Umar ra. wafat, 'A İ Ibnu Abì Țālib ra. mengemukakan pendapat yang berbeda dengan itu. 'Aז berpendapat bahwa ummu al-walad itu berbeda dengan hamba sahaya biasa, ia merdeka dengan sendirinya dengan kematian tuannya. Dengan demikian, untuk kepastian suatu ijmak harus ditunggu berlalunya masa sehingga wafatnya semua mujtahid peserta ijmak."

Sementara jumhūr ulama (yang mayoritas pengikut madzhab Syafi'’i) dan Abū

${ }^{15}$ Ahmad Syaripudin, Buku Ajar Metodologi Studi Islam, (Cet. I; Surabaya: Pustaka Media Guru, 2019), h. 22.

${ }^{16}$ Abdul Majid Khon, Ulum al-Hadis, (Cet. I; Jakarta: Amzah, 2012), h. 147.

${ }^{17}$ Amir Syarifuddin, Ushul Fiqh, (Cet. V; Jakarta: Kencana Prenada Media Group, 2011), h. 152.

Ahmad Syaripudin, M. Kasim. Konsep Dasar Ijmak... 
Hanifah berpendapat bahwa berlalunya masa dan meninggalnya para mujtahid yang tergabung dalam ijmak bukanlah salah satu syarat sahnya ijmak sebagai sebuah dalil. Jika terjadi kesepakatan di antara para mujtahid atas suatu hukum syarī pada waktu tertentu, maka kesepakatan tersebut cukup dikatakan sebagai ijmak. Argumentasi ini diperkuat dengan beberapa dalil sebagai berikut:

Pertama, bahwa sandaran ijmak adalah al-Qur'an dan hadis Nabi saw. Keduanya tidak memerlukan berlalunya waktu untuk ditetapkannya sebagai hujah. Dengan demikian ijmak yang bersandar pada keduanya pun tidak memerlukan berlalunya waktu sebagai salah satu syarat kehujahan ijmak.

Kedua, fakta sejarah membuktikan bahwa para tabiin di penghujung masa sahabat, seperti Anas ra. dan lainnya berhujah dengan ijmak para sahabat. Secara logika, seandainya berlalunya masa merupakan syarat atas kekuatan kehujahan ijmak, maka tabiin tidak akan berhujah dengan hasil ijmak para sahabat pada masa dimana masa sahabat masih hidup.

Ketiga, ijmak adalah sebuah kesepakatan atas ketetapan hukum suatu perkara yang tidak ditemukan dalil yang jelas dalam al-Qur'an dan atau hadis Nabi. Maka substansi dari ijmak adalah kesepakatan, bukan meninggalnya sebagian atau semua imam mujtahid yang terlibat dalam ijmak. Jadi, kekuatan ijmak tergantung pada kesepakatan.

7. Tidak diperbolehkan ada hukum ijmak sebelumnya yang berkaitan dengan permasalahan yang sama.

\section{Kedudukan Ijmak sebagai Landasan Ilmu dan Hukum Islam}

Kedudukan ijmak dalam posisinya sebagai sumber ilmu dan hukum Islam menempati deretan ketiga setelah al-Qur-an dan hadis.

\section{Kedudukan Ijmak Dilandasi oleh Al-Qur'an, di antaranya: ${ }^{18}$}

1. Q.S. al-Nisa/4: 115 .

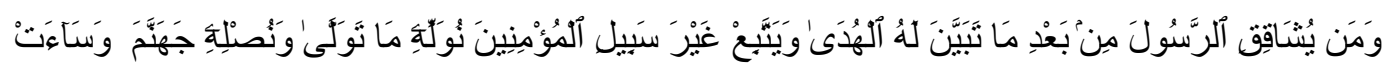

Terjemahnya: Barangsiapa menentang rasul (Muhammad saw.) setelah jelas

${ }^{18}$ Asmawi, Perbandingan Ushul Fiqh (Jakarta: Amzah, 2011), h. 86-88. 
baginya kebenaran, dan mengikuti jalan yang bukan jalannya orang-orang mukmin, Kami biarkan ia berkuasa terhadap kesesatan dan Kami akan masukkan ia ke dalam neraka jahanam, dan neraka jahanam itu adalah seburuk-buruk tempat kembali.

2. Q.S. al-Baqarah/2: 143 .

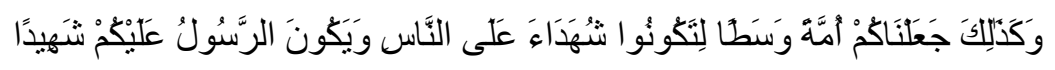

Terjemahnya: Dan demikian (pula) kami telah menjadikan kamu (umat Islam), umat yang adil dan pilihan agar kamu (Muhammad) menjadi saksi atas (perbuatan) kamu.

3. Q.S. Luqman/31: 15.

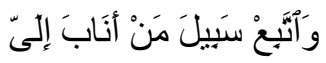

Terjemahnya: Dan ikutilah jalan orang yang kembali kepada-Ku (Allah).

4. Q.S. al-A'raf/7: 181.

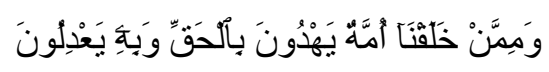

Terjemahnya: Dan diantara orang-orang yang kami ciptakan, ada umat yang memberi petunjuk dengan kebenaran, dan dengan kebenaran itu (pula) mereka menjalankan keadilan.

Kedudukan Ijmak Dilandasi oleh Hadis, di antaranya:

1. Hadis Ibnu Umar ra. yang diriwayatkan oleh Imam Tirmizi:

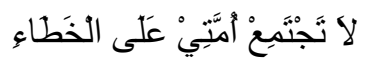

Artinya: Umatku tidak mungkin bersepakat terhadap sesuatu yang keliru.

2. Hadis Mu'awiyah ibnu Abi Sufyan ra. yang diriwayatkan oleh Imam Bukhari dan Imam Muslim:

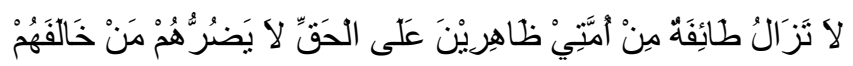

Artinya: Senantiasa segolongan umatku membela/menegakkan kebenaran, dan tidak akan membahayakan mereka, orang-orang yang menentang mereka. 
BUSTANUL FUQAHA: Jurnal Bidang Hukum Islam

Vol. 1, No. 1 (2020) : Hal. 28-43

Website: httpas://journal.stiba.ac.id

\section{Ijmak sebagai Sumber Pengambilan Ilmu dan Hukum Islam}

Alasan menjadikan ijmak sebagai sumber dalam pengambilan ilmu dan hukum Islam adalah sebagai berikut: ${ }^{19}$

1. Imam al-Syāfi'i pernah ditanya mengapa beliau mengikuti ijmak. Beliau meminta waktu selama tiga hari untuk menjawab pertanyaan tersebut, karena beliau biasa menghatamkan al-Qur'an dalam waktu tiga hari. Sesudah tiga hari, maka beliau menjawab dengan ayat berikut ini:

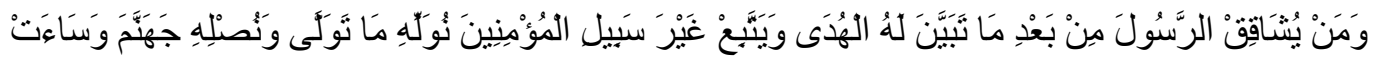

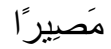

Terjemahnya: Barangsiapa menentang rasul setelah jelas baginya kebenaran, dan mengikuti jalan yang bukan jalannya orang-orang mukmin, Kami biarkan ia berkuasa terhadap kesesatan dan Kami akan masukkan ia ke dalam jahanam, dan jahanam itu seburuk-buruk tempat kembali. (QS. Al-Nisa/4: 115).

Menurut para Mufassir سَيَيل المُؤْينِينَ dalam ayat di atas maksudnya adalah jalannya para sahabat. Hal itu karena orang yang beriman ketika ayat itu turun adalah para sahabat.

2. Ijmak dilandasi oleh al-Qur'an dan sunah. Para salaf saleh tidak berijmak kecuali di atas dalil yang sahih. Ibnu Taimiyah mengatakan: “ijmak yang dhabit (kuat) adalah ijmaknya para salaf saleh, karena setelah mereka, sudah banyak pertentangan dan perbendaan pendapat dan umat sudah berpencar ke beberapa negeri."

3. Mustahil manusia dapat bersepakat di atas kebatilan. Rasulullah saw. bersabda bahwa "Umatku tidak akan bersepakat di atas satu kesesatan." Ini bukan berarti bahwa umat Muhammad saw. itu tidak ada yang melakukan kesesatan tapi yang dimaksudkan adalah bahwa kalau ada di antara umat ini melakukan kesesetan, maka tidak mungkin semua umat ini $100 \%$ setuju pada kesesatan itu. Akan senantiasa ada satu kelompok yang menentang hal tersebut sehingga kesimpulannya bahwa umat ini tidak mungkin sepakat kecuali di atas al-haq (kebenaran). Oleh karena itu, ketika seseorang ingin digolongkan dalam golongan firqatun najiah hendaknya dia mengambil ketiga

\footnotetext{
${ }^{19}$ Ahmad Syaripudin, Buku Ajar Metodologi Studi Islam, (Cet. I; Surabaya: Pustaka Media Guru, 2019), h. 14-16.
} 
sumber ini dalam membentuk akidahnya.

\section{Jenis-jenis Ijmak}

Disebutkan dalam kitab Ușūl Fiqh karya Abu Zahrah, ijmak dibagi menjadi dua yaitu ijmak șan̄h dan ijmak sukūtī. ${ }^{20}$

\section{Ijmak Sarīh}

Ijmak $S a n ̄ h h$ adalah suatu kesepakatan atas suatu permasalahan yang diungkapkan secara langsung oleh para mujtahid pada suatu masa. Misalnya, jika dihadapkan pada mereka suatu permasalahan yang tidak ada dalilnya dalam al-Qur'an secara jelas, kemudian satu di antara mereka menyikapi permasalahan tersebut dan diikuti oleh yang lain dengan sikap yang sama, hingga terjadi sebuah kesepakatan di antara mereka atas permasalahan yang dihadapkan. ${ }^{21}$ Kesepakatan ini baik berupa ungkapan dari masing-masing para mujtahid, tulisan yang dipublikasikan atau berbentuk perbuatan. Ijmak ini tidak harus dilakukan dalam satu tempat dengan cara mengumpulkan semua imam mujtahid di suatu negeri. Tapi bisa dilakukan dengan cara yakni salah seorang mujtahid mengemukakan pendapatnya (berfatwa) atas suatu permasalahan, kemudian pendapat ini didengar oleh mujtahid yang lain dan mereka berpendapat yang sama dengan yang pertama. Maka ini disebut sebagai ijmak. ${ }^{22}$ Sebagian ulama juga berpendapat bahwa ijmak șan̄h ini sangat langka, dan hanya bisa terjadi pada masa sahabat. Sebab pada masa itu jumlah mujtahid masih tergolong sedikit dan bisa dijangkau secara tempat domisili. Ijmak șan̄h ditinjau dari kekuatan dilālah-

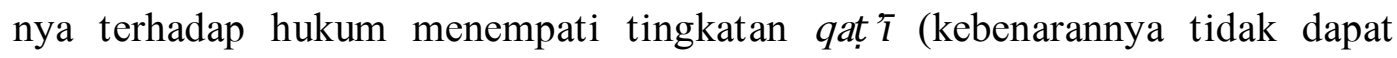
diragukan). ${ }^{23}$

\section{Ijmak Sukūtī}

Ijmak sukūtī adalah suatu pendapat yang dikemukakan oleh salah seorang mujtahid, kemudian pendapat tersebut populer di kalangan para imam mujtahid yang hidup pada satu masa. Tetapi para imam mujtahid yang lainnya tidak mengingkari atau membantah pendapat yang dikemukakan oleh mujtahid yang pertama, mereka memilih diam dan tak berkomentar apa-apa. Oleh sebagian ulama dipahami bahwa diamnya mereka merupakan indikasi atas

${ }^{20}$ Muhammad Abū Zahrah, Ușūl Fiqh, (Multazam al-Ṭabi’u wa al-Nașr. Dār al-Fikr al'Azalī. 1958), h. 317.

${ }^{21}$ Abd al-Karīm Zaidān, al-Waj̄̄z fi Ușūl al-Fiqh, h. 180.

${ }^{22}$ Abd al-Karīm Zaidān, al-Waj̄̄z fi Ușūl al-Fiqh, h. 180.

${ }^{23}$ Amir Syarifuddin, Ushul Fiqh, (Cet. V; Jakarta: Kencana Prenada Media Group, 2011), h. 159. 
kesetujuannya. $^{24}$ Terkait ijmak sukūtī ini, ulama berbeda pendapat dalam menyikapinya, apakah ia bisa disebut sebagai ijmak (dalam arti sebagai sumber hukum Islam) atau tidak?, perbedaan ini paling tidak dipecah menjadi tiga kelompok yaitu:

Pertama, Ijmak sukūtī ini tidak dapat disebut sebagai ijmak. Pendapat ini dikemukakan oleh Imām al-Syāfi'ì dan mayoritas ulama fikih. Argumentasi yang dibangun oleh Imam Syāfi'ì adalah bahwa orang yang tidak berbicara (diam) tidak bisa diklaim dengan persetujuan mereka atas sesuatu yang disodorkan padanya. Sebab, mereka berdiam diri karena belum melakukan ijtihad.

Kedua, ijmak sukūtī merupakan dalil qaț ’’ yang tidak boleh diingkari. Sebab, ia sama seperti ijmak șan̄h walaupun secara kualitas masih berada di bawah ijmak șan̄h. Oleh karena diamnya mereka menunjukkan kesepakatan/persetujuannya. Pendapat ini merupakan pendapat mayoritas pengikut Imam Abu Hanifah dan pendapat Imam Ahmad bin Hambal. ${ }^{25}$

Ketiga, ijmak sukūtī bukanlah sebuah ijmak tetapi lebih tepat disebut sebagai daīl dzannī. Pendapat ini dikemukakan oleh sebagian ulama dari kalangan Hanafiyah dan Syafi'iyah. Sebab, diam bukanlah sikap persetujuan yang jelas. Bisa saja orang memaknainya berbeda. ${ }^{26}$

Adapun Syekh Muhammad bin Salih al-Usaimin ra. membagi ijmak ke dalam dua bagian lain, yaitu Ijmak Qat'i dan Ijmak Dzanni: ${ }^{27}$ Pertama, ijmak Qat'i, yaitu ijmak yang diketahui oleh umat Islam secara jelas dan urgen seperti ijmak atas kewajiban salat lima waktu, pengharaman zina, ini jenis ijmak yang qat' $i$ dan tidak ada seorang pun yang mengingkarinya secara sengaja kecuali dia kafir atau keluar dari Islam. Kedua, ijmak Dzanni, yaitu ijmak yang dapat diketahui dengan usaha keras setelah mempelajari beberapa dalil dan kemungkinan beberapa ulama berbeda pendapat dalam kemungkinan terjadinya ijmak tersebut.

\section{Bentuk-bentuk Ijmak Fikih Klasik: ${ }^{28}$}

\section{Bentuk Ijmak Berlandaskan Al-Qur'an}

${ }^{24}$ Muhammad Abū Zahrah, Ușūl Fiqh, (Multazam al-Ṭabi’u wa al-Nașr. Dār al-Fikr al'Azalī. 1958), h. 318.

${ }^{25}$ Abd al-Karīm Zaidān, al-Waj̄̄z fì Ușūl al-Fiqh, h. 183.

${ }^{26} \mathrm{Abd}$ al-Karīm Zaidān, al-Waj̄̄z fì Ușūl al-Fiqh, h. 185.

${ }^{27}$ https://islamqa.info/ar/answers/201682/

${ }^{28}$ https://www.alukah.net/sharia/0/73778/ 
1. Kesepakatan para ulama tentang keharaman menikahi nenek dan cucuk perempuan berdasarkan firman Allah Ta'ala dalam Q.S. al-Nisa/4: 23.

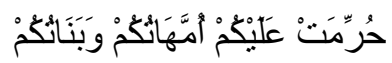

Terjemahnya: Diharamkan atas kamu (mengawini) ibu-ibumu; anak-anakmu yang perempuan.

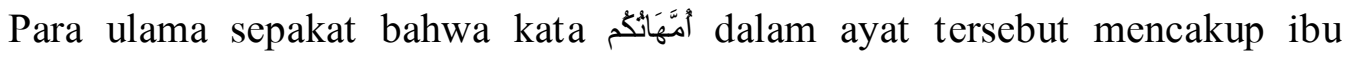
kandung dan nenek, sedangkan kata بَنَاْكَّم dersebut mencakup anak perempuan dan cucuk perempuan.

2. Posisi cucuk laki-laki dari anak laki-laki dalam pembagian waris satu posisi berdasarkan firman Allah Ta'ala dalam Q.S. al-Nisa/4: 11.

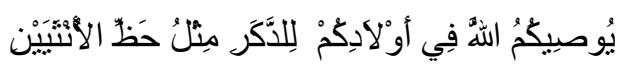

Terjemahnya: Allah mensyari'atkan bagimu tentang (pembagian pusaka untuk) anak-anakmu. Ialah bahagian seorang anak laki-laki sama dengan bahagian dua orang anak perempuan.

\section{Bentuk Ijmak Berlandaskan Hadis}

Bagian warisan bagi nenek mendapatkan bagian 1/6 ketika tidak ada ibu.

\section{Bentuk Ijmak Berlandaskan Ijtihad Sahabat dan Maslahat Positif}

1. Ijmak sahabat untuk mengodifikasi al-Qur'an dikarenakan ada maslahat positif yang tampak dilakukan pada masa khalifah Abu Bakar al-Shiddiq ra.

2. Ijmak sahabat untuk adanya azan awal untuk salat jumat untuk memanggil kaum muslimin persiapan melaksanakan salat jumat terutama yang jarak rumahnya jauh dari masjid yang diprakarsai oleh sahabat Utsman bin Affan r.a. pada masa kekhalifahan beliau.

3. Ijmak untuk boleh adanya manajemen sistem organisasi keuangan, yayasan, kantor, ormas untuk mengatur urusan sosial negeri atau swasta.

\section{Bentuk Ijmak Fikih Kontemporer}

Keabsahan dalam transplantasi organ manusia, kematian otak, kloning hewan dan manusia, perusahaan saham gabungan, pertukaran saham, globalisasi, dan kepatuhan terhadap lembaga internasional, peraturan dan undang-undang seperti Organisasi Perdidikan Dunia dan Organisasi Perdagangan Dunia. 


\section{Hukum Mengingkari Ijmak}

Terkait hukum mengingkari ijmak, maka Syekh Salih bin Fauzan al-Fauzan berkata: ${ }^{29}$

"Hukum orang yang mengingkari ijmak secara mutlak ini adalah kafir keluar dari Islam, tetapi orang yang menyangkal beberapa bentuk ijmak, maka dirinci perkataan/pendapatnya, apakah itu benar atau salah? Apakah betul yang dia ingkari itu ijmak atau bukan. Adapun orang yang menyangkal ijmak dalam Islam, seperti ijmak dalam masalah kewajiban akidah, tauhid, haramnya riba, haramnya zina, dan beberapa hal yang jelas hukumnya dalam Islam secara umum, maka hukum orang tersebut adalah kafir."

\section{KESIMPULAN}

1. Ijmak adalah kesepakatan para ulama mujtahid dari umat Nabi Muhammad saw. atas persoalan agama/syar'ī yang tidak ditemukan dalilnya secara jelas dalam al-Qur'an dan hadis pada suatu masa setelah masa Nabi saw. yang mempunyai rukun-rukun dan syarat-syarat tertentu.

2. Kedudukan ijmak dalam posisinya sebagai sumber ilmu dan hukum Islam menempati deretan ketiga setelah al-Qur'an dan hadis.

3. Jenis ijmak diantara ijmak șan̄h dan ijmak sukūtī, dan ada yang membagi menjadi ijmak Qat'i dan Ijmak Dzanni.

4. Beberapa bentuk ijmak:

a. Bentuk ijmak fikih klasik: 1) kesepakatan para ulama tentang keharaman menikahi nenek dan cucuk perempuan berdasarkan Q.S. al-Nisa/4: 23; 2) posisi cucuk laki-laki dari anak laki-laki dalam pembagian waris satu posisi berdasarkan Q.S. al-Nisa/4: 11;3) bagian warisan bagi nenek mendapatkan bagian 1/6 ketika tidak ada ibu; 4) ijmak sahabat untuk mengodifikasi alQur'an karena ada maslahat positif yang tampak dilakukan pada masa khalifah Abu Bakar al-Shiddiq ra.

b. Bentuk ijmak fikih kontemporer: keabsahan dalam transplantasi organ tubuh manusia, kematian otak, kloning hewan dan manusia, perusahaan saham gabungan, pertukaran saham, globalisasi, dan kepatuhan terhadap lembaga internasional, peraturan dan undang-undang seperti organisasi pendidikan dunia dan organisasi perdagangan dunia.

5. Hukum orang yang mengingkari ijmak secara mutlak (totalitas) ini adalah kafir keluar dari Islam.

\footnotetext{
${ }^{29}$ https://alfawzan.af.org.sa/ar/node/2387
} 


\section{DAFTAR PUSTAKA}

Abū Zahrah, Muhammad. (1958). Ușūl Fiqh. Multazam al-Ṭabi’u wa al-Nașr. Dār al-Fikr al-'Azalī.

Ahmad Syaripudin. (2019). Buku Ajar Metodologi Studi Islam, Cet. I; Surabaya: Pustaka Media Guru.

al-As'adī, Muhammad Ubaidillah. (2001). Al-Maujiz fi Ușūl Fiqh. Cet. II. Mesir:

Dār al-Salam.

Asmawi. (2011). Perbandingan Ushul Fiqh. Jakarta: Amzah.

al-Wazīr, Ahmad bin Muhammad bin 'Alī. (1996). al-Mușțafã fi Ușūl al-Fiqh.

Cet. I; Beirut: Dar al-Fikr.

al-Zarkasyî, Badr al-Din Muhammad ibn 'Abdillah. (1992). Al-Bahr al-Muhith fi Ushul al-Fiqh, Jilid. 6, Cet. II; Wizaratul Auqaf.

al-Zuhailī, Muhammad Muțafā.(2006). Al-Waj̄̄z fi Ușūl al-Fiqh al-Islāmī. Dār al-Khair. Cet. II. Juz. I.

Bakry, K. (2018). Konsep Syūrā dalam al-Quran. NUKHBATUL'ULUM: Jurnal Bidang Kajian Islam, 4(1), 70-83.

Hakim, 'Abd al-Ḥamīd. (2007). Al-Sullam. Juz. II. Jakarta. Maktabah alSa'adiyah Putra.

Haroen, Nasrun.(1997). Ushul Fiqh. Jakarta: Logos Wacana Ilmu.

Ibn al-Najar, Muhammad bin Ahmad bin Abd al-Aziz. (1997). al-Kaukab alMunir Syarah Mukhtasar al-Tahrir, Jilid 1, Cet. I; Maktabah al-'Abikan.

Iskandar, A., Aqbar, K. (2019). Green Economy Indonesia Dalam Perspektif Maqashid Syari'ah. Al-Mashrafiyah: Jurnal Ekonomi, Keuangan, dan Perbankan Syariah,3(2), h.83-94.

Khallaf, Abdul Wahab.(2002). Ilm Ușūl Fiqh. Cet. XII; Dār al-Fikr.

Khon, Abdul Majid. (2012). Ulum al-Hadis, Cet. I; Jakarta: Amzah.

Syafiruddin, Amir. (2011). Usul Fiqh. Cet. V. Jakarta: Kencana Prenada Media Group.

Zaidān, 'Abd al-Karīm. Al-Waj̄z Fi Ușūl al-Fiqh. Muassasah al-Risālah. t.th. . 2019. https://alfawzan.af.org.sa/ar/node/2387. (19 September 2019). .2019. https://alukah.net/sharia/0/73778/. (25 September 2019). . 2019. https://islamqa.info/ar/answers/201682/. (29 September 2019). 